\title{
Agnieszka Łuszpak
}

Uniwersytet Wrocławski, Wrocław, Polska

agnieszka.luszpak@uwr.edu.pl

(iD) 0000-0002-2926-5745

https://doi.org/10.33077/uw.25448730.zbkh.2021.686

\section{Polskie czasopisma filozoficzne w okresie międzywojennym - szkic}

\author{
Philosophical journals \\ in the interwar period in Poland - draft
}

\begin{abstract}
According to historians of philosophy Second Republic of Poland, in spite of the modest time frame, was the "golden period of Polish philosophy". It is therefore worthwhile to look at the philosophical periodicals of this period, as they provide an excellent reflection of university life and one of the most important forms of scientific communication. In addition, "Przegląd Filozoficzny" from Warsaw, "Kwartalnik Filozoficzny" from Krakow, "Ruch Filozoficzny” and "Studia Philosophica" from Lviv, are indispensable tools for promoting Polish philosophical culture in a newly united nation.
\end{abstract}

Key words: philosophical periodicals - interwar period - Poland

Słowa kluczowe: czasopisma filozoficzne - okres międzywojenny - Polska 
Narody żyją kulturą, a tworząc ją, odkrywają w niej swoją tożsamość, swój logos i ethos. U podstaw zaś każdej kultury stoi filozofia, która dostarcza rozumienia świata i człowieka, determinując przez to ludzkie kulturotwórcze działanie

\section{Wstęp}

Grupa czasopism fachowych i naukowych stanowiła, obok czasopism ogólnoinformacyjnych, najliczniejszą grupę periodyków w okresie międzywojennym. Na tle 216 czasopism naukowych obecnych na polskim rynku wydawniczym w 1926 r., 284 tytułów w roku 1930 czy ponad $400 \mathrm{w} 1935$ r. ${ }^{1}$, dziesięć czasopism filozoficznych, o których będzie mowa w niniejszym szkicu, nie wydaje się stanowić znaczącego wkładu w czasopiśmiennictwo naukowe. Jednak biorąc pod uwagę, że okres ten zapisał się złotymi zgłoskami w dziejach filozofii polskiej (znana w całym świecie lwowsko-warszawska szkoła filozoficzna wtedy właśnie święciła największe triumfy), warto przyjrzeć się tym właśnie periodykom.

Pierwsze czasopismo typowo filozoficzne powstało na ziemiach polskich już pod koniec XIX w. („Przegląd Filozoficzny” 1897 r.), jednak zdaniem historyków filozofii to II Rzeczpospolita, mimo stosunkowo skromnych ram czasowych, stanowiła „złoty okres” filozofii polskiej. Warto więc z pewnością przyjrzeć się funkcjonowaniu tej grupy czasopism naukowych w II RP, jako że stanowią one doskonałe odbicie życia uniwersyteckiego $\mathrm{i}$ jedną z najważniejszych form komunikacji naukowej. To właśnie fakt odzyskania przez Polskę niepodległości radykalnie wpłynął na rozwój filozofii, głównie dzięki rozwojowi instytucji naukowych. W okresie międzywojennym z pewnością łatwiej było uprawiać filozofię niż w poprzedniej epoce - przed I wojną światową były tylko dwa uniwersytety (Kraków i Lwów) z wykładowym polskim, które jeszcze przed 1918 r. stanowiły ośrodki kultury filozoficznej. Zaraz potem pojawiły się te nowe - lub odnowione - w Warszawie, Lublinie, Wilnie i Poznaniu. Ponadto obok już istniejących towarzystw filozoficznych, których rola w rozwoju nauk filozoficznych jest nie do przecenienia (Polskie Towarzystwo Filozoficzne we Lwowie 1904 r., Towarzystwo Filozoficzne w Krakowie 1909 r., Warszawski Instytut Filozoficzny 1915 r.) pojawiły się nowe - poznańskie w 1925 r., wileńskie w 1928 r. oraz warszawskie, z połączonego Instytutu Filozoficznego i Polskiego Towarzystwa Psychologicznego, istniejącego już od 1907 r. i zrzeszającego głównie filozofów. Towarzystwa te działały na terenie

1 Por. A. Paczkowski, Prasa polska w latach 1918-1939, Warszawa 1980; G. Wrona, Polskie czasopisma naukowe w latach 1918-1939, Kraków 2005. 
całej odrodzonej Polski, podobnie jak uniwersytety. Poza tym filozofowie zaangażowani byli często $\mathrm{w}$ działalność innych instytucji naukowych, takich jak Warszawskie Towarzystwo Naukowe, Towarzystwo Naukowe we Lwowie, Komisję Filozoficzną Poznańskiego Towarzystwa Przyjaciół Nauk czy Akademię Umiejętności w Krakowie, nie brakowało więc forów wymiany myśli.

W kontekście rozwoju filozofii w omawianym okresie warto jeszcze wspomnieć o zjazdach filozoficznych. Odbyły się wtedy aż trzy. Już wcześniej filozofowie spotykali się na kongresach, lecz w ramach spotkań lekarzy czy przedstawicieli nauk przyrodniczych. W 1911 r., podczas jednego z takich spotkań naukowych pojawił się pomysł, by zorganizować zjazd typowo filozoficzny. Udało się go wcielić w życie dopiero kilka lat po odzyskaniu niepodległości. Odbył się we Lwowie, w 1923 r. Co ważne, podczas tego zjazdu przyjęto uchwały dotyczące propagowania kultury filozoficznej w społeczeństwie. Miało ono polegać na intensywnych pracach przekładowych i wydawniczych oraz zwiększeniu liczby godzin nauczania filozofii w szkołach (toczyły się na ten temat dyskusje na łamach czasopism filozoficznych). W 1927 r. odbył się kolejny zjazd, w Warszawie, a w 1936 r. w Krakowie (poruszający problem stosunków między filozofią a współczesną nauką). Ponadto polscy filozofowie uczestniczyli w międzynarodowych spotkaniach filozofów (Oksford 1930, Praga 1934, Paryż 1937 r.) i właśnie na łamach periodyków filozoficznych dzielili się informacjami na temat tego, co dzieje się w filozofii europejskiej.

Widać więc, iż w okresie międzywojennym nastąpiło już w pełni to, co w naukoznawstwie określa się mianem ,instytucjonalizacji nauki”. Dzięki temu mogły toczyć się dyskusje na temat roli i zadań filozofii, dysputy o filozofii narodowej, o patriotyzmie czy nacjonalizmie w kontekście filozofii. Padały postulaty ,przywrócenia intelektualnej tradycji naszego narodu”2 przez wznowienia dzieł największych przedstawicieli filozofii narodowej. Uznano, że to ważne dla kształtowania świadomości obywateli świeżo odrodzonego państwa, choć samo pojęcie „filozofia narodowa” uznano za trudne do zdefiniowania. W każdym razie na łamach czasopism, podczas odczytów czy zjazdów można było prowadzić dyskusje na ważkie filozoficzne tematy oraz dzięki nim upowszechniać kulturę filozoficzną wśród polskiej inteligencji.

Co ważne, w epoce tej ostatecznie już nauki szczegółowe oddzieliły się od filozofii. Jeszcze w XIX i na początku XX w. wywodzące się od Arystotelesa pojmowanie filozofii jako „nauki nauk” utrudniało wyodrębnienie zagadnień czysto filozoficznych z ogromu zagadnień naukowych i zebranie tychże w jednym piśmie. Może dlatego właśnie dopiero pod koniec XIX w. powstał „Przegląd Filozoficzny”.

2 K. Bochenek i in., Filozofia polska okresu międzywojennego. Zarys problematyki, Gdynia 2013, s. 6 . 


\section{Czasopisma filozoficzne ${ }^{3}$}

To, że przed końcem XIX w. nie istniały czasopisma typowo filozoficzne, nie znaczy oczywiście, że nie publikowano materiałów z zakresu „królowej nauk”. Na przykład na łamach „Monitora” już w 2. poł. XVIII w. prezentowano treści filozoficzne. Potem właściwie wszystkie czasopisma o charakterze kulturalnym czy naukowym zamieszczały rozprawy tego typu, zwłaszcza od czasów pozytywizmu, by wymienić tylko „Przegląd Tygodniowy”, „Bibliotekę Warszawskąa”, „Ateneum” czy „Pamiętnik Warszawski”.

Tabela 1. Największe czasopisma filozoficzne ukazujące się w Polsce w okresie międzywojennym ${ }^{4}$

\begin{tabular}{|c|c|c|c|c|c|}
\hline & $\begin{array}{l}\text { Data po- } \\
\text { wstania }\end{array}$ & $\begin{array}{l}\text { Miejsce } \\
\text { wydania }\end{array}$ & $\begin{array}{l}\text { Często- } \\
\text { tliwość }\end{array}$ & Redaktor naczelny & Wydawca \\
\hline $\begin{array}{l}\text { „Przegląd } \\
\text { Filozoficzny” }\end{array}$ & 1897 & $\begin{array}{l}\text { Warszawa } \\
\text { + filie: } \\
\text { Lwów, } \\
\text { Kraków, Po- } \\
\text { znań, Wilno, } \\
\text { Lublin }\end{array}$ & $\begin{array}{l}\text { Kwartal- } \\
\text { nik }\end{array}$ & $\begin{array}{c}\text { 1897-1915 Władysław } \\
\text { Weryho; 1916-1918 } \\
\text { Jan Łukasiewicz; } 1919- \\
1923 \text { Marian Borowski; } \\
\text { 1924-1946 Władysław } \\
\text { Tatarkiewicz }\end{array}$ & $\begin{array}{l}\text { 1897-1927 War- } \\
\text { szawski Instytut } \\
\text { Filozoficzny, } \\
\text { od 1928 Warszaw- } \\
\text { skie Towarzystwo } \\
\text { Filozoficzne }\end{array}$ \\
\hline $\begin{array}{l}\text { „Ruch } \\
\text { Filozoficzny” }\end{array}$ & 1911 & $\begin{array}{l}\text { Lwów + fi- } \\
\text { lie: Poznań, } \\
\text { Kraków, } \\
\text { Wilno, } \\
\text { Warszawa }\end{array}$ & $\begin{array}{l}\text { Mie- } \\
\text { sięcznik, } \\
\text { od } 1939 \\
\text { kwartal- } \\
\text { nik } \\
\end{array}$ & $\begin{array}{c}1911-1937 \\
\text { Kazimierz Twardowski; } \\
\text { 1938-1939 } \\
\text { Daniela Gromska, } \\
\text { Izydora Dąmbska }\end{array}$ & $\begin{array}{l}\text { Polskie } \\
\text { Towarzystwo } \\
\text { Filozoficzne } \\
\text { w Krakowie }\end{array}$ \\
\hline $\begin{array}{l}\text { „Kwartalnik } \\
\text { Filozoficzny” }\end{array}$ & 1922 & Kraków & Rocznik & $\begin{array}{c}\text { 1922-1935 Władysław } \\
\text { Heinrich; 1935-1937 } \\
\text { Zygmunt Zawirski, } \\
\text { Marian Heitzman; } 1939 \\
\text { Z. Zawirski }\end{array}$ & $\begin{array}{l}\text { Polska Akademia } \\
\text { Umiejętności } \\
\text { w Krakowie, To- } \\
\text { warzystwo Filozo- } \\
\text { ficzne w Krakowie }\end{array}$ \\
\hline $\begin{array}{c}\text { „Studia } \\
\text { Philosophica” }\end{array}$ & 1935 & Lwów & $\begin{array}{l}\text { Nieregu- } \\
\text { larnie }\end{array}$ & $\begin{array}{c}\text { Kazimierz Ajdukiewicz, } \\
\text { K. Twardowski, } \\
\text { Roman Ingarden }\end{array}$ & $\begin{array}{l}\text { Polskie Towarzy- } \\
\text { stwo Filozoficzne } \\
\text { we Lwowie }\end{array}$ \\
\hline $\begin{array}{l}\text { "Archiwum } \\
\text { Komisji } \\
\text { do Badania } \\
\text { Historii } \\
\text { Filozofii } \\
\text { w Polsce" }\end{array}$ & $\begin{array}{l}1915- \\
1937\end{array}$ & Kraków & Rocznik & Nie podano & $\begin{array}{c}\text { Komisja do } \\
\text { Badania Historii } \\
\text { Filozofii w Polsce } \\
\text { przy Polskiej Aka- } \\
\text { demii Umiejętno- } \\
\text { ści w Krakowie }\end{array}$ \\
\hline
\end{tabular}

3 Szczegółowe przedstawienie strony formalno-wydawniczej opisywanych czasopism z pewnością przekraczałoby ramy niniejszego szkicu. Informacje tego typu znaleźć można w tekstach z zakresu historii filozofii poświęconych poszczególnym periodykom czy w hasłach poświęconych poszczególnym tytułom w Encyklopedii filozofii polskiej. W niniejszej pracy chodzi raczej o pokazanie koncepcji programowych i zawartości najważniejszych tytułów.

4 Wszystkie tabele zamieszczone w tekście - opracowanie własne. 
Jednak to właśnie w okresie międzywojennym obserwujemy powstanie kilku specjalistycznych czasopism, poświęconych wyłącznie filozofii, a także rozkwit już istniejących (por. Tab. 1). To niewątpliwy dowód na istnienie dużego środowiska filozoficznego oraz osób zainteresowanych tą tematyką, nawet jeśli niezwiązanych zawodowo z filozofią. Przyjmuje się, że w tym okresie nastąpiła zmiana jakościowa i ilościowa jeśli chodzi o czasopiśmiennictwo filozoficzne. Pisma te powstawały w największych ośrodkach - Warszawa, Lwów, Kraków, potem także Poznań i Gniezno. Jak połowa periodyków naukowych ukazujących się w okresie II RP, wydawane były przez różne towarzystwa naukowe ${ }^{5}$. To zróżnicowanie zapewniało przestrzeń do dyskusji i prezentacji różnorakich poglądów filozoficznych, choć mówiąc o filozofii okresu międzywojennego, najczęściej przywołuje się słynną szkołę lwowsko-warszawską. Jednak nurt ten z pewnością nie wyczerpywał ówcześnie panoramy polskiej myśli filozoficznej, o czym jeszcze będzie mowa.

Wszystkie istniejące ówcześnie pisma filozoficzne miały swój udział w rozwoju polskiej filozofii, choć największe zasługi przyznaje się „Przeglądowi”. Uznawany jest za czasopismo wiodące, nadające ton, najważniejsze w tamtym okresie. Jak skonstatował filozof i historyk filozofii Jan Woleński „Filozofia polska pierwszej połowy XX w. tworzyła się w przeważającej mierze na łamach Przeglądu"6.

Jaki cel postawił sobie pierwszy redaktor naczelny „Przeglądu”, W. Weryho? Ten niestrudzony organizator życia filozoficznego w Polsce chciał, by czasopismo zachęcało do zajmowania się filozofią, zwłaszcza młodych badaczy, do dzielenia się wynikami badań, miało także zintegrować środowisko filozofów oraz informować o ruchu naukowym w Polsce i za granicą ${ }^{7}$. Wprawdzie deklaracja ta pochodzi z 1897 r., jednak nic nie wskazuje na to, by potem profil pisma się zmienił. To pierwsze polskie czasopismo filozoficzne miało być centrum wymiany myśli, reagować na współczesne trendy filozoficzne, budować polską filozofię nawiązując do światowej ${ }^{8}$. Stanowiło także kronikę życia filozoficznego, ale tylko przez pierwszych kilkanaście lat swego istnienia, do momentu powstania „Ruchu Filozoficznego” w 1911 r. Ten ostatni był miesięcznikiem, a nie kwartalnikiem, jak „Przegląd”, więc lepiej nadawał się do zadań sprawozdawczych, do pełnienia funkcji kroniki i informowania o życiu filozoficznym. K. Twardowski, twórca lwowsko-warszawskiej szkoły filozoficznej, jeden z najwybitniejszych filozofów tamtego okresu popierał zamiar założenia czasopisma przez Weryhę ${ }^{9}$, a kilkanaście lat później sam założył kolejne pismo, czyli „Ruch Filozoficzny”. W założeniu periodyki te miały się uzupełniać - „Ruch” założono w porozumieniu i niejako z „błogosławieństwem” redakcji „Przeglądu”.

5 Por. G. Wrona, Polskie czasopisma naukowe..., s. 33.

6 J. Woleński, ,, O Przeglądzie Filozoficznym ”, ,Ruch Filozoficzny” 1985, nr 1-2, s. 38.

7 Por. W. Weryho, Stowo wstępne, ,Przegląd Filozoficzny” 1897, t. 1, z. 1, s. 3.

8 Por. Encyklopedia filozofii polskiej. T. 1, red. A. Maryniarczyk, Lublin 2011, s. 224.

9 Por. J. Woleński, Filozofia szkoły lwowsko-warszawskiej, Wrocław 1986, s. 10. 
Oba pisma prowadziły wspólną prenumeratę i wspomagały się w pracy w swych filiach. Jak pisał przywoływany już Woleński, ówcześnie poziom świadomości filozoficznej „,wśród ludzi nauki był nieprzeciętny i nigdy potem nie osiągnął już takiego pułapu"10, co nie powinno dziwić, skoro w każdej szkole średniej przynajmniej przez rok nauczano filozofii. W związku z tym „Przegląd” nie był w stanie podołać wszystkim zadaniom stawianym periodykowi naukowemu - nie mógł jednocześnie zamieszczać wartościowych, wyczerpujących prac problemowych oraz zajmować się rejestracją bieżących wydarzeń w kraju i za granicą. „Ruch” miał go w tym wyręczyć.

Na łamach „Przeglądu” w interesującym nas okresie publikowano głównie obszerne rozprawy naukowe dotyczące epistemologii, logiki, metodologii nauk, etyki, estetyki, historii filozofii, psychologii czy socjologii, także polemiki i sprawozdania z najnowszej literatury filozoficznej. A „Ruch” stanowił poniekąd jego wydzieloną część, z działem spraw bieżących. W związku z tym dział artykułów był w nim mocno okrojony, zwykle zamieszczano ich niewiele (od jednego do trzech); dotyczyły postaci najwybitniejszych filozofów, spraw organizacji pracy naukowej w filozofii czy dydaktyki filozofii, nieraz $\mathrm{w}$ formie zaproszenia do dyskusji. Prym wiódł dział recenzji, zwykle były to krótkie omówienia dzieł i monografii polskich i zagranicznych. Także przegląd czasopism stanowił ważną część periodyku, podobnie sprawozdania z prac i obrad towarzystw filozoficznych, relacje ze zjazdów i kongresów, wiadomości bieżące na temat odczytów, wykładów, konkursów, wiadomości ze świata akademickiego (np. fakt objęcia przez któregoś z filozofów katedry akademickiej etc.). Tego typu doniesienia składały się na tak zwany - nomen omen - ruch filozoficzny i stanowiły zasadniczą część periodyku. Zamieszczano także bibliografię. Nawet układ „Ruchu” był charakterystyczny dla prasy codziennej, a nie naukowej, czyli dwukolumnowy.

Pismo to miało trafić do szerokiego grona odbiorców - informacje o nim znalazły się także w prasie codziennej, na przykład po śmierci K. Twardowskiego przypomniano w notkach prasowych, że tytuł ten służyć chce nie tylko specjalistom z zakresu filozofii, że chce zacieśniać więzy między naukami filozoficznymi a innymi dyscyplinami. Tak przedstawiano zawartość:

Sprawozdania krytyczne z literatury filozoficznej polskiej i obcej, przegląd czasopism filozoficznych polskich, angielskich, francuskich i niemieckich wraz ze streszczeniami ostatnich zeszytów, szczegółową bibliografię filozoficzną polską i zagraniczną, sprawozdania z prac i obrad Towarzystw filozoficznych [...], wiadomości bieżące o dotyczących filozofii wydawnictwach, odczytach, wykładach, zjazdach, konkursach oraz wiadomości osobiste ${ }^{11}$.

10 J. Skoczyński, J. Woleński, Historia filozofii polskiej, Kraków 2010, s. 519.

11 Por. Zapiski. Ruch Filozoficzny - notatka o Ruchu Filozoficznym po śmierci K. Twardowskiego, „Express Wieczorny” (Lwów) 30 listopada 1938, nr 2631. Nr spisu inw. P.9,4, [online] 
W „Wieku Nowym” ponadto usprawiedliwiano się z zaległości w informowaniu o bieżącym ruchu filozoficznym i zapewniano, że redaktorzy „starają się o utrzymanie ciągłości służby informacyjnej" i będą podawać aktualności ${ }^{12}$.

W. Heinrich, redaktor naczelny „Kwartalnika Filozoficznego”, trzeciego dużego periodyku tamtego okresu, misję i strategię pisma przedstawił w artykule wstępnym ${ }^{13}$. Filozof ten, specjalizujący się w historii filozofii i psychologii współpracował przy tworzeniu periodyku z przedstawicielami różnych nurtów - Konstanty Michalski reprezentował myśl katolicką, Jan Michał Rozwadowski był językoznawcą, Witold Rubczyński zajmował się filozofią kultury. Na początku lat 30. do grona redakcji dołączyli także filolog klasyczny Adam Krokiewicz, historycy filozofii W. Tatarkiewicz (zasadniczo redaktor „Przeglądu Filozoficznego") oraz M. Heitzman i logik Z. Zawirski. Redakcja zamierzała informować o filozofii europejskiej poprzez zamieszczanie opracowań na temat dokonań poszczególnych myślicieli i prezentację nurtów tejże filozofii, poprzez recenzje zagranicznych wydawnictw, a także zamieszczanie sprawozdań z kongresów. Program tego pisma był więc typowy dla czasopism naukowych, łącząc w sobie cechy naukowego „Przeglądu” i sprawozdawczego „Ruchu”.

Czwarte z najważniejszych, jak się powszechnie uznaje, czasopism filozoficznych tamtego okresu, czyli „Studia Philosophica” tym głównie różniło się od reszty, że przeznaczone było dla zagranicznego odbiorcy. Inicjatorem był K. Ajdukiewicz (logik i epistemolog), we współpracy z fenomenologiem R. Ingardenem i ontologiem K. Twardowskim (redaktorem „Ruchu Filozoficznego"). Prezentowało podobne treści, co poprzednie tytuły, tyle że strony redakcyjne były prowadzone po łacinie (był więc podział na: disputationes, relationes, index praelectionum), a artykuły publikowano w językach obcych, po niemiecku czy francusku. Jego redaktorzy deklarowali, że dzięki powstaniu tego periodyku wzrośnie wzajemna wspólnota oraz komunikacja naukowa między uczonymi polskimi a zagranicznymi. A skoro chcieli zaprezentować światu polską filozofię, to oczywiście skupili się na publikacji rozpraw naukowych, często obszernych, a także recenzowaniu prac polskich filozofów - choć nie zawsze były to typowe recenzje. Czasem przypominały raczej krótkie notki na temat danej pracy, nierzadko przygotowywane przez samego autora. Recenzowano także rozprawy zamieszczane na łamach czasopism, zarówno tych typowo filozoficznych, jak i ogólnonaukowych czy z innych dziedzin („Przegląd

https://archiwum.polaczonebiblioteki.uw.edu.pl/themencode-pdf-viewer/?file=https://archiwum.polaczonebiblioteki.uw.edu.pl/wp-content/uploads/2021/04/AKT-P-09-4.pdf [dostęp 4.10.2021].

12 Por. Zapiski. Ruch Filozoficzny - notatka o Ruchu Filozoficznym po śmierci K. Twardowskiego, „Wiek Nowy” (Lwów) 27 listopada 1938, nr 11.269. Nr spisu inw. P.9,5. [online] https:// archiwum.polaczonebiblioteki.uw.edu.pl/themencode-pdf-viewer/?file=https://archiwum.polaczonebiblioteki.uw.edu.pl/wp-content/uploads/2021/04/AKT-P-09-5.pdf [dostęp 4.10.2021].

13 W. Heinrich, Filozofia i jej zadania, „Kwartalnik Filozoficzny” 1922, z. 1, s. 18. 
Humanistyczny”, „Nauka Polska” czy „Kwartalnik Psychologiczny”). Ponadto „Studia Philosophica” zamieszczały informacje o życiu filozoficznym w postaci wykazów prelekcji, które miały miejsce w danym okresie w różnych towarzystwach filozoficznych w Polsce. Z czasopism ukazujących się przez prawie cały okres dwudziestolecia warto jeszcze wspomnieć krakowskie „Archiwum Komisji do Badania Historii Filozofii w Polsce". Inicjatywa stworzenia tego periodyku wyszła z Komisji do Badania Historii Filozofii w Polsce, istniejącej przy Polskiej Akademii Umiejętności w Krakowie. Mimo że pismo miało być rocznikiem, na przestrzeni 22 lat ukazało się zaledwie 6 tomów. Było całkowicie pozbawione funkcji informacyjnej, zawierało tylko obszerne, o objętości właściwej raczej książkom niż artykułom (100 i 200-stronicowe) rozprawy problemowe z pogranicza filozofii i filologii.

Tabela 2. Inne czasopisma filozoficzne w Polsce w okresie międzywojennym

\begin{tabular}{|c|c|c|c|c|c|}
\hline $\begin{array}{l}\text { „Archiwum Historii } \\
\text { i Filozofii Medycyny" } \\
\text { (w 1. 1925-1939: } \\
\text { „Archiwum Historii } \\
\text { i Filozofii Medycyny } \\
\text { oraz Historii Nauk } \\
\text { Przyrodniczych") }\end{array}$ & 1925-1937 & Poznań & $\begin{array}{c}\text { Kwartalnik, } \\
\text { 1924-1931 } \\
\text { półrocznik, } \\
\text { od } 1932 \\
\text { nieregularnie }\end{array}$ & $\begin{array}{c}\text { Adam } \\
\text { Wrzosek }\end{array}$ & $\begin{array}{c}\text { Polskie } \\
\text { Towarzystwo } \\
\text { Historii } \\
\text { Medycyny } \\
\text { i Farmacji } \\
\text { w Poznaniu }\end{array}$ \\
\hline $\begin{array}{l}\text { „Biuletyn Posiedzeń } \\
\text { Naukowych War- } \\
\text { szawskiego Instytutu } \\
\text { Filozoficznego" }\end{array}$ & 1923-1926 & Warszawa & & $\begin{array}{l}\text { Bolesław } \\
\text { Gawecki }\end{array}$ & $\begin{array}{l}\text { Warszawski } \\
\text { Instytut } \\
\text { Filozoficzny }\end{array}$ \\
\hline „Studia Gnesnensia” & 1933 & Gniezno & & $\begin{array}{l}\text { Kazimierz } \\
\text { Kowalski }\end{array}$ & $\begin{array}{l}\text { Seminarium } \\
\text { Duchowne } \\
\text { w Gnieźnie }\end{array}$ \\
\hline
\end{tabular}

Mniej znane tytuły, ukazujące się w interesującym nas okresie, także poświęcone filozofii (Tab. 2), to „Archiwum Historii i Filozofii Medycyny”, które miało być płaszczyzną debaty dla historii i filozofii medycyny. Założyciel i redaktor, nazwany przez W. Tatarkiewicza filozofem medycyny, Adam Wrzosek ${ }^{14}$, cytując opinię historyka medycyny Władysława Szumowskiego w deklaracji programowej z dnia 25 III 1924 r. podkreślał, iż ,wlanie filozoficznego ducha w wykład historii nauki jest postulatem współczesnej historii" ${ }^{15}$. Powoływał się na dokonania Jana Śniadeckiego czy Tytusa Chałubińskiego, a także prace zamieszczane w „Krytyce Lekarskiej”, której nowe pismo miało być w pewnym sensie kontynuatorem. Wrzosek uważał, że wobec rozwoju historii i filozofii

14 Por. W. Tatarkiewicz, Historia filozofii. T. 3, Warszawa 1990, s. 367.

15 A. Wrzosek, Zadania i zamierzenia polskiego, „Archiwum Historii Medycyny i Filozofii Medycyny" 1924, t. 1, z. 1, s. 6. 
medycyny - nauk, które w dwudziestoleciu zyskały status nauk uniwersyteckich, istnieje wręcz konieczność założenia pisma publikującego rozprawy z tych konkretnie dziedzin. W praktyce jednak pismo skupiało się na historii medycyny, z filozofii zamieszczano zwykle jeden tylko artykuł ${ }^{16}$, choć pojawiały się także prace, które dziś zaliczylibyśmy do bioetyki.

W latach 1923-1926 ukazały się jeszcze cztery roczniki „Biuletynu Posiedzeń Naukowych Warszawskiego Instytutu Filozoficznego", w którym zamieszczano teksty wystąpień i sprawozdania z tytułowych posiedzeń; po powstaniu Warszawskiego Towarzystwa Filozoficznego Biuletyn stracił rację bytu i przestał się ukazywać. Katolickie „Studia Gnesnensia” teoretycznie były czasopismem, ale wychodziły jako seria monografii, do wybuchu II wojny ukazało się 17 tomów. Publikowano w nich rozprawy filozoficzne i teologiczne, także w językach obcych - po niemiecku, francusku czy po łacinie, często były to prace doktorskie obronione na zagranicznych uniwersytetach. Czasopismo to miało stanowić forum prezentacji myśli neoscholastycznej.

Przed samym wybuchem wojny, w 1939 r. powstały dwa kolejne pisma filozoficzne (Tab. 3) i trudno się nie zastanawiać, czy był to wyraz iście kandydowskiego optymizmu, czy stereotypowe, filozoficzne bujanie w obłokach i niezwracanie uwagi na sytuację polityczną. „Polski Przegląd Tomistyczny” (Lwów) oraz „Wronskiana” (Warszawa) z przyczyn oczywistych nie miały szans się rozwinąć.

Tabela 3. Czasopisma filozoficzne powstałe w 1939 r.

\begin{tabular}{|c|c|c|c|c|c|}
\hline $\begin{array}{c}\text { „Polski Przegląd } \\
\text { Tomistyczny” }\end{array}$ & 1939 & Lwów & Kwartalnik & $\begin{array}{c}\text { Józef Maria Bocheński, } \\
\text { Andrzej Gmurkowski }\end{array}$ & $\begin{array}{c}\text { Wydawnictwo } \\
\text { OO. Dominikanów }\end{array}$ \\
\hline $\begin{array}{c}\text { "Wronskiana. Rocz- } \\
\text { nik Filozoficzno- } \\
\text {-Matematyczny” }\end{array}$ & 1939 & $\begin{array}{c}\text { War- } \\
\text { szawa }\end{array}$ & Rocznik & Jerzy Braun & $\begin{array}{c}\text { Towarzystwo Ho- } \\
\text { ene-Wrońskiego }\end{array}$ \\
\hline
\end{tabular}

Jak już wspomniano, czasopisma fachowe i naukowe stanowiły w okresie międzywojennym znaczącą grupę. Jednak wiele $\mathrm{z}$ nich to były tak zwane efemerydy - 20\% znikało z rynku po roku, kolejne $20 \%$ w ciągu trzech-pięciu lat ${ }^{17}$. Na tym tle pozytywnie wyróżniają się czasopisma filozoficzne. Najbardziej znaczące tytuły okazały się przedsięwzięciami nadzwyczaj trwałymi, choć

16 Jakkolwiek w świetle powyższych uwag o znaczącej przewadze artykułów z zakresu historii medycyny nad filozoficznymi, przynależność tego periodyku do grupy pism filozoficznych może budzić wątpliwości (G. Wrona, opisując czasopisma filozoficzne okresu międzywojennego, nie uwzględniła tego tytułu), jednak moim zdaniem rozstrzygające jest wymienienie tego pisma w artykule Czasopisma filozoficzne w Polsce, w Encyklopedii filozofii polskiej, na równi z „Przeglądem Filozoficznym” czy „Ruchem Filozoficznym”. Tytuł ten pojawia się także w opracowaniach dotyczących filozofii tego okresu jako przykład czasopisma filozoficznego.

17 Por. G. Wrona, Polskie czasopisma naukowe..., s. 30. 
przecież tematyka ta nie należała do najłatwiejszych czy najbardziej popularnych, nawet biorąc pod uwagę wysoki stopień kultury filozoficznej ówczesnej inteligencji. O trudnościach, z jakimi borykali się twórcy pism filozoficznych najlepiej świadczyć może wspomnienie W. Tatarkiewicza:

Kiedy Władysław Weryho zakładał «Przegląd Filozoficzny», to miał w swoim pokoju biurko i na tym biurku leżały papiery dotyczące «Przeglądu Filozoficznego»”. A gdy w 1925 r. przejąłem po Werysze redakcję, sytuacja jeszcze się pogorszyła, bo nie było nawet oddzielnego biurka. Na jednym biurku leżały papiery uniwersyteckie i redakcyjne ${ }^{18}$.

Przykład mizerii finansowej pokazuje także list Tatarkiewicza do K. Twardowskiego: „Może bardziej jeszcze niż słaby udział autorów, dotkliwym staje się słabe zainteresowanie czytelników. Pomimo do maximum doprowadzonej oszczędności, nie możemy drukować bez subwencji i to dużej”"19. Kolejne tomy pism filozoficznych wychodziły z opóźnieniem, łączono numery, jednak redaktorzy nie ustawali w staraniach o dotacje rządowe i zdobycie nowych prenumeratorów, byle tylko utrzymać ciągłość wydawniczą.

\section{Autorzy i tematyka czasopism filozoficznych}

Czasopiśmiennictwo filozoficzne stanowi - w pewnej mierze oczywiście odbicie życia filozoficznego w danej epoce. Pokazuje zainteresowania naukowe zarówno indywidualne, jak i zbiorowe uczonych. Obraz ten jest w miarę dokładny w przypadku omawianych tu czasopism, gdyż na ich łamach prezentowano przede wszystkim dokonania autorów polskich. Początkowo planowano zamieszczać także prace zagraniczne, zwłaszcza że obawiano się (obawy takie wyrażał m.in. W. Weryho, pierwszy redaktor „Przeglądu”), że zabraknie prac polskich filozofów czy myślicieli, jednak obawy te się nie sprawdziły. Materiałów było aż nadto, co zresztą dobrze świadczy o rozwoju polskiej filozofii w tamtej epoce - ukazywało się jednocześnie kilka periodyków, a nie brakowało prac problemowych i recenzji do publikowania. Warto spojrzeć, jak przedstawiała się kwestia rozpraw publikowanych na łamach czasopism filozoficznych pod kątem ilościowym. Obrazują to tabele 4 i 5, przedstawiające odpowiednio artykuły i recenzje zamieszczane w najważniejszych analizowanych czasopismach ${ }^{20}$.

18 W. Tatarkiewicz, Wypowiedź w dyskusji nad ksiązka Konrada Olchowicza „Ćwierć wieku z Kurierem Warszawskim”, „Kronika Warszawy” 1980, nr 4 (44), s. 80.

19 Por. R. Jadczak, 80 lat „Ruchu Filozoficznego, „Ruch Filozoficzny” 1991, nr 2, s. 101.

20 W zestawieniu wzięto jedynie pod uwagę rozprawy problemowe. Podano liczby dla całego rocznika, ze względu na nieregularność w ukazywaniu się periodyków - pismo, które miały być kwartalnikiem czy miesięcznikiem i tak nierzadko ukazywało się wspólnie, de facto jako rocznik, tyle że z podziałem na numery. Nie uwzględniono zamieszczanych na łamach czasopism wystąpień konferencyjnych wygłaszanych podczas zjazdów filozoficznych w Polsce czy za granicą. 
Ze względu na różną częstotliwość ich ukazywania się właściwie nie sposób dokonać porównań ilościowych, widać tylko wyraźnie, że „Ruch” koncentrował się na materiałach informacyjno-recenzyjnych, a „Przegląd” na prezentowaniu artykułów problemowych. „Kwartalnik” z kolei z powodzeniem łączył obie te funkcje. Za najważniejszy periodyk niewątpliwie uchodzi „Przegląd”, ale to na łamach „Ruchu” publikowano informacje dotyczące życia filozoficznego, przeznaczone dla szerszego grona odbiorców, nie tylko zawodowych filozofów, ale też miłośników tej nauki oraz dla przedstawicieli innych dyscyplin.

Tabela 4. Liczba artykułów ${ }^{21}$

\begin{tabular}{|c|c|c|c|c|c|}
\hline & PF & RF & $\mathbf{K F}$ & SP & AK \\
\hline 1918 & 9 & & & & \\
\hline 1919 & 13 & & & & \\
\hline 1920 & 21 & 6 & & & \\
\hline 1921 & 9 & 6 & & & 1 \\
\hline 1922 & 19 & \multirow{2}{*}{2} & & & \\
\hline 1923 & 9 & & 11 & & \\
\hline 1924 & 11 & 6 & 9 & & \\
\hline 1925 & 8 & 6 & 10 & & \\
\hline 1926 & 9 & \multirow{2}{*}{3} & 7 & & 3 \\
\hline 1927 & 9 & & 9 & & \\
\hline 1928 & 7 & \multirow{2}{*}{1} & 9 & & \\
\hline 1929 & 9 & & 12 & & \\
\hline 1930 & 10 & \multirow{2}{*}{3} & 13 & & 1 \\
\hline 1931 & 8 & & 6 & & \\
\hline 1932 & 5 & & 6 & & \\
\hline 1933 & 12 & & 6 & & 2 \\
\hline 1934 & 6 & & 8 & & \\
\hline 1935 & 11 & \multirow{3}{*}{3} & 11 & 6 & \\
\hline 1936 & 9 & & 11 & & \\
\hline 1937 & 20 & & 12 & 6 & 1 \\
\hline 1938 & 15 & 2 & 13 & & \\
\hline 1939 & 9 & & & & \\
\hline Suma & 238 & 38 & 153 & 12 & 8 \\
\hline
\end{tabular}

21 We wszystkich tabelach zastosowano akronimy nazw analizowanych czasopism: $\mathrm{PF}=$ „Przegląd Filozoficzny”; RF = „Ruch Filozoficzny”; KW = „Kwartalnik Filozoficzny”; SP = „Studia Philosophica”; $\mathrm{AK}=$ „Archiwum Komisji do Badania Historii Filozofii w Polsce”. 
Tabela 5. Liczba recenzji

\begin{tabular}{|c|c|c|c|c|c|}
\hline & PF & RF & KW & SP & AK \\
\hline \multicolumn{6}{|l|}{1918} \\
\hline \multicolumn{6}{|l|}{1919} \\
\hline 1920 & & 19 & & & \\
\hline 1921 & & 13 & & & \\
\hline 1922 & 5 & \multirow{2}{*}{15} & & & \\
\hline 1923 & 5 & & 17 & & \\
\hline 1924 & 3 & 13 & 15 & & \\
\hline 1925 & 12 & 15 & 20 & & \\
\hline 1926 & 14 & \multirow{2}{*}{12} & 11 & & \\
\hline 1927 & 7 & & 9 & & \\
\hline 1928 & 3 & \multirow{2}{*}{11} & 10 & & \\
\hline 1929 & 6 & & 6 & & \\
\hline 1930 & 12 & \multirow{2}{*}{17} & 5 & & \\
\hline 1931 & 23 & & 6 & & \\
\hline 1932 & 16 & & 4 & & \\
\hline 1933 & 56 & & 5 & & \\
\hline 1934 & 19 & & 1 & & \\
\hline 1935 & 24 & \multirow{3}{*}{16} & 7 & 56 & \\
\hline 1936 & 18 & & 15 & & \\
\hline 1937 & 11 & & 15 & 55 & \\
\hline 1938 & 22 & 6 & 4 & & \\
\hline 1939 & 6 & & & & \\
\hline Suma & 262 & 137 & 150 & 111 & \\
\hline
\end{tabular}

Historycy filozofii podkreślają prymat instytucjonalny lwowsko-warszawskiej szkoły filozoficznej założonej przez K. Twardowskiego w okresie międzywojennym $^{22}$. Uczniowie Twardowskiego objęli w tym czasie katedry filozofii i psychologii (w tamtym okresie nauka ta jeszcze nie do końca oddzieliła się od filozofii) na wszystkich polskich uniwersytetach poza Katolickim Uniwersytetem Lubelskim (Lwów - po Twardowskim K. Ajdukiewicz; Warszawa - J. Łukasiewicz, T. Kotarbiński, Stanisław Leśniewski, W. Tatarkiewicz; Wilno - Tadeusz Czeżowski; Poznań i Kraków - Z. Zawirski). Przedstawiciele szkoły redagowali najważniejsze polskie czasopisma filozoficzne (J. Łukasiewicz, M. Borowski, W. Tatarkiewicz, D. Gromska, I. Dąmbska, Z. Zawirski, K. Ajdukiewicz, B. Gawecki, K. Kowalski, J.M. Bocheński) i stali na czele towarzystw filozoficznych (Lwów, Kraków, Warszawa, Wilno).

22 Por. J. Jadacki, Filozofia polska XIX i XX wieku. T. 2: Wiek XIX, Warszawa 2015, s. 13-15, J. Woleński, Filozofia szkoły..., s. 13. 
Nic więc dziwnego, że artykuły pisane przez reprezentantów tej szkoły dominowały w czasopiśmiennictwie filozoficznym w II RP, skoro pod koniec tego okresu szkoła lwowsko-warszawska liczyła ok. 80 osób, które pozostawiły po sobie kilka tysięcy utworów ze wszystkich dziedzin filozofii ${ }^{23}$. Część tego dorobku widać na łamach czasopism filozoficznych ${ }^{24}$ (Tab. 6-18). Bogactwo nurtów i doktryn to cecha charakterystyczna tej formacji intelektualnej, gdyż jak pisał historyk filozofii polskiej, Stanisław Borzym:

W szkole filozoficznej Twardowskiego [...] nie tyle obowiązywała jedność doktrynalna, ile przestrzeganie pewnej metody filozofowania, a ściślej, pewnych reguł filozofowania, polegających na jasnym i wyraźnym definiowaniu pojęć, na dokładnej analizie znaczeń, precyzji terminologicznej, na skrupulatnym uzasadnianiu wygłaszanych twierdzeń [...]. Refleksja, która nie spełniała tych zasad, nie była, zdaniem Twardowskiego, godna miana nauki ${ }^{25}$.

Widoczny jest maksymalny wręcz pluralizm zainteresowań, a zatem wśród prac przedstawicieli tej szkoły znajdziemy zarówno te dotyczące bytu (Tab. 6), jak i wartości - czy to etycznych (Tab. 8) czy estetycznych (Tab. 7). Rozprawy traktujące o poznaniu (Tab. 17), jak i te, których tematyka oscyluje wokół psychologii (Tab. 18) czy pedagogiki (Tab. 16). Artykuły na temat filozofii społecznej (Tab. 9), ale też historii filozofii (Tab. 10). Sporo miejsca na łamach czasopism zajęły rozprawy logiczne (Tab. 12), jako że ta właśnie dziedzina stanowiła jedno z głównych pól zainteresowań filozofów ze szkoły lwowsko-warszawskiej.

Tabela 6.

\begin{tabular}{|c|c|c|c|c|c|c|c|c|}
\hline \multirow{2}{*}{$\begin{array}{c}\text { Szkoła lwowsko-war- } \\
\text { szawska - byt }\end{array}$} & \multicolumn{2}{|c|}{ PH } & \multicolumn{2}{c|}{ RF } & \multicolumn{2}{c|}{ KF } & SP & AK \\
\cline { 2 - 9 } & Art. & Rec. & Art. & Rec. & Art. & Rec. & & \\
\hline Borowski M. & 13 & 7 & & 2 & & & & \\
\hline Twardowski K. & & & 4 & 3 & & & & \\
\hline
\end{tabular}

23 Por. J. Jadacki, Filozofia polska..., s. 14, J. Woleński, Filozofia szkoty..., s. 3.

24 W analizach pominięto kilku autorów, których tożsamości nie udało się jednoznacznie ustalić, ale na ogólny obraz, biorąc pod uwagę liczbę zidentyfikowanych nazwisk, nie ma to wpływu. Ze względu na to, że sami historycy filozofii nie zawsze mogą właściwie sklasyfikować myślicieli i niektórych opatrują jedynie ogólnikowym mianem „,filozof”, w niektórych przypadkach także pozostałam przy tym określeniu. Oczywiście określenie danego filozofa jako epistemologa czy ontologa zawsze jest poniekąd arbitralne, zwłaszcza że wielu z nich zajmowało się różnymi dziedzinami filozofii, jednak był to konieczny zabieg porządkujący. Posiłkowałam się podstawowymi źródłami, podanymi w bibliografii.

25 Zarys dziejów filozofii polskiej 1815-1918, red. A. Walicki, Warszawa 1986, s. 488. 
Tabela 7.

\begin{tabular}{|c|c|c|c|c|c|c|c|c|}
\hline \multirow{2}{*}{$\begin{array}{c}\text { Szkoła lwowsko-war- } \\
\text { szawska - estetyka }\end{array}$} & \multicolumn{2}{|c|}{ PH } & \multicolumn{2}{c|}{ RF } & \multicolumn{2}{c|}{ KF } & SP & AK \\
\cline { 2 - 9 } & Art. & Rec. & Art. & Rec. & Art. & Rec. & & \\
\hline Milbrandt Mieczysław & & 3 & & & & & & \\
\hline Wallis-Walfisz Mieczysław & 3 & & & & & & 1 & \\
\hline
\end{tabular}

Tabela 8 .

\begin{tabular}{|c|c|c|c|c|c|c|c|c|}
\hline \multirow{2}{*}{$\begin{array}{c}\text { Szkola lwowsko-war- } \\
\text { szawska - etyka }\end{array}$} & \multicolumn{2}{|c|}{ PH } & \multicolumn{2}{c|}{ RF } & \multicolumn{2}{c|}{ KF } & SP & AK \\
\cline { 2 - 9 } & Art. & Rec. & Art. & Rec. & Art. & Rec. & & \\
\hline Czeżowski T. & 9 & 2 & 2 & 2 & & & & \\
\hline Elzenberg Henryk & 4 & 5 & & 1 & & & & \\
\hline
\end{tabular}

Tabela 9.

\begin{tabular}{|c|c|c|c|c|c|c|c|c|}
\hline \multirow{2}{*}{$\begin{array}{c}\text { Szkola lwowsko-war- } \\
\text { szawska - filozofia } \\
\text { spoleczna }\end{array}$} & \multicolumn{2}{|c|}{ PH } & \multicolumn{2}{c|}{ RF } & \multicolumn{2}{|c|}{ KF } & SP & AK \\
\cline { 2 - 9 } & Art. & Rec. & Art. & Rec. & Art. & Rec. & & \\
\hline Lempicki Zygmunt & 2 & & & 5 & & & 1 & \\
\hline Ossowska Maria & 4 & 3 & & 1 & 3 & & & \\
\hline Ossowski Stanisław & 1 & & & 1 & & & & \\
\hline
\end{tabular}

Tabela 10.

\begin{tabular}{|c|c|c|c|c|c|c|c|c|}
\hline $\begin{array}{c}\text { Szkola lwowsko-war- } \\
\text { szawska- historia } \\
\text { filozofii }\end{array}$ & \multicolumn{2}{|c|}{ PH } & \multicolumn{2}{c|}{ RF } & \multicolumn{2}{c|}{ KF } & SP & AK \\
\cline { 2 - 9 } & Art. & Rec. & Art. & Rec. & Art. & Rec. & & \\
\hline Bad Hersch & 1 & & & 1 & & & & \\
\hline Świeżawski Stefan & 1 & 1 & & & & & & \\
\hline Tatarkiewicz W. & 6 & 12 & 1 & 1 & 1 & 1 & 1 & 1 \\
\hline Witwicki Władysław & 4 & & 1 & 13 & & & & \\
\hline
\end{tabular}

Tabela 11.

\begin{tabular}{|c|c|c|c|c|c|c|c|c|c|}
\hline \multirow{2}{*}{$\begin{array}{l}\text { Szkoła lwowsko- } \\
\text {-warszawska - } \\
\text { inne specjalności }\end{array}$} & & \multicolumn{2}{|c|}{ PH } & \multicolumn{2}{|c|}{ RF } & \multicolumn{2}{|c|}{ KF } & \multirow[t]{2}{*}{ SP } & \multirow[t]{2}{*}{ AK } \\
\hline & & Art. & Rec. & Art. & Rec. & Art. & Rec. & & \\
\hline Blaustein Leopold & fenomenologia & 2 & & 1 & 2 & & & & \\
\hline Mosdorf Jan & historiozofia & & 3 & & & & & & \\
\hline $\begin{array}{l}\text { Ostrowski-Naumof } \\
\text { Jan }\end{array}$ & filozofia & & & & & & & & \\
\hline Smolka Franciszek & mesjanizm & 1 & & & & & & & \\
\hline
\end{tabular}


Tabela 12.

\begin{tabular}{|c|c|c|c|c|c|c|c|c|}
\hline \multirow{2}{*}{$\begin{array}{c}\text { Szkoła lwowsko-war- } \\
\text { szawska- logika }\end{array}$} & \multicolumn{2}{|c|}{ PH } & \multicolumn{2}{c|}{ RF } & \multicolumn{2}{c|}{ KF } & SP & AK \\
\hline & Art. & Rec. & Art. & Rec. & Art. & Rec. & & \\
\hline $\begin{array}{c}\text { Hosiasson-Lindenbaumo- } \\
\text { wa Janina }\end{array}$ & 1 & 1 & & & & & & \\
\hline Igel Salomon & 3 & & & & 1 & & & \\
\hline Jordan Zbigniew Antoni & 2 & & & & & & & \\
\hline Kaczorowski Stanisław & 1 & & & & & & & \\
\hline Leśniewski S. & 5 & & & & & & & \\
\hline Lukasiewicz J. & 2 & & & & 1 & & & \\
\hline Mehlberg Henryk & & 1 & & 2 & 1 & & 2 & \\
\hline Mostowski Andrzej & & & & & 1 & & & \\
\hline Sobociński Bolesław & 1 & 12 & & & & & & \\
\hline \multirow{2}{*}{ Tarski (Tajtelbaum) Alfred } & 4 & & & & & & & \\
\hline Zawirski Z. & 2 & 1 & 3 & 8 & 7 & 10 & 1 & \\
\hline
\end{tabular}

Tabela 13.

\begin{tabular}{|c|c|c|c|c|c|c|c|c|}
\hline $\begin{array}{c}\text { Szkoła lwowsko-war- } \\
\text { szawska - } \\
\text { metodologia nauk }\end{array}$ & \multicolumn{2}{|c|}{ PH } & \multicolumn{2}{c|}{ RF } & \multicolumn{2}{c|}{ KF } & SP & AK \\
\cline { 2 - 9 } & Art. & Rec. & Art. & Rec. & Art. & Rec. & & \\
\hline $\begin{array}{c}\text { Kokoszyńska-Lutmanowa } \\
\text { Maria }\end{array}$ & 2 & & 1 & 4 & 1 & 1 & & \\
\hline Pański Antoni & & 1 & & & & & & \\
\hline $\begin{array}{c}\text { Kotarbińska Janina } \\
\text { (Sztejnbarg Dina) }\end{array}$ & 3 & 3 & & 1 & 1 & & & \\
\hline
\end{tabular}

Tabela 14.

\begin{tabular}{|c|c|c|c|c|c|c|c|c|}
\hline \multirow{2}{*}{$\begin{array}{c}\text { Szkola lwowsko-war- } \\
\text { szawska- myśl katolicka }\end{array}$} & \multicolumn{2}{|c|}{ PH } & \multicolumn{2}{c|}{ RF } & \multicolumn{2}{c|}{ KF } & SP & AK \\
\hline & Art. & Rec. & Art. & Rec. & Art. & Rec. & & \\
\hline Bocheński J.M. & 1 & 1 & & & & & & \\
\hline $\begin{array}{c}\text { Drewnowski } \\
\text { Jan Franciszek }\end{array}$ & 3 & 4 & & & & & & \\
\hline Salamucha Jan & 2 & 7 & & & & 3 & & \\
\hline
\end{tabular}


Tabela 15.

\begin{tabular}{|c|c|c|c|c|c|c|c|c|c|}
\hline \multirow{2}{*}{$\begin{array}{c}\text { Szkoła lwowsko- } \\
\text {-warszawska - } \\
\text { nauki historyczne }\end{array}$} & \multicolumn{2}{|c|}{ PH } & \multicolumn{2}{|c|}{ RF } & \multicolumn{2}{|c|}{ KF } & SP & AK \\
\hline & & Art. & Rec. & Art. & Rec. & Art. & Rec. & & \\
\hline Kleiner Juliusz & $\begin{array}{c}\text { historia i teoria } \\
\text { literatury }\end{array}$ & 1 & & & 3 & & & & \\
\hline Szumowski W. & $\begin{array}{c}\text { historia } \\
\text { medycyny }\end{array}$ & 1 & & & 1 & & & & \\
\hline Treter Mieczysław & historia sztuki & 1 & & & 3 & & & & \\
\hline
\end{tabular}

Tabela 16.

\begin{tabular}{|c|c|c|c|c|c|c|c|c|}
\hline \multirow{2}{*}{$\begin{array}{c}\text { Szkoła lwowsko-war- } \\
\text { szawska - pedagogika }\end{array}$} & \multicolumn{2}{|c|}{ PH } & \multicolumn{2}{c|}{ RF } & \multicolumn{2}{c|}{ KF } & SP & AK \\
\cline { 2 - 9 } & Art. & Rec. & Art. & Rec. & Art. & Rec. & & \\
\hline Nawroczyński Bogdan & 1 & 2 & & & & 1 & & \\
\hline Sośnicki Kazimierz & 1 & & & 1 & & & & \\
\hline
\end{tabular}

Tabela 17.

\begin{tabular}{|c|c|c|c|c|c|c|c|c|}
\hline \multirow{2}{*}{$\begin{array}{c}\text { Szkoła lwowsko-war- } \\
\text { szawska - poznanie }\end{array}$} & \multicolumn{2}{|c|}{ PH } & \multicolumn{2}{c|}{ RF } & \multicolumn{2}{c|}{ KF } & SP & AK \\
\cline { 2 - 10 } & Art. & Rec. & Art. & Rec. & Art. & Rec. & & \\
\hline Ajdukiewicz K. & 4 & & 1 & 2 & & & 1 & \\
\hline Dąmbska I. & 2 & & & 3 & 3 & & & \\
\hline Gawecki B. & 5 & 6 & 2 & 3 & 2 & 5 & & \\
\hline Gromska D. & 1 & & 1 & 4 & & & & \\
\hline Kotarbiński Tadeusz & 8 & 8 & 4 & 5 & & 1 & 1 & \\
\hline Wiegner Adam Florian & & & & 2 & 1 & 5 & & \\
\hline
\end{tabular}

Tabela 18.

\begin{tabular}{|c|c|c|c|c|c|c|c|c|}
\hline \multirow{2}{*}{$\begin{array}{c}\text { Szkola lwowsko-war- } \\
\text { szawska - psychologia }\end{array}$} & \multicolumn{2}{|c|}{ PH } & \multicolumn{2}{c|}{ RF } & \multicolumn{2}{c|}{ KF } & SP & AK \\
\hline & Art. & Rec. & Art. & Rec. & Art. & Rec. & & \\
\hline Auerbach Walter & 1 & & & 3 & & & & \\
\hline Baley Stefan & 3 & & & 3 & & & & \\
\hline Błachowski Stefan & 2 & & 3 & 6 & & & & \\
\hline Geblewicz Eugeniusz & & 3 & & & & & & \\
\hline Kreutz Mieczysław & & & & 2 & & & & \\
\hline Słoniewska Helena & & & & 1 & & & & \\
\hline
\end{tabular}


Jednak nie wszystkie teksty zamieszczane na łamach czasopism filozoficznych stanowiły pokłosie dokonań szkoły lwowsko-warszawskiej. Jak pokazują poniższe zestawienia (tab. 19-30), filozofowie spoza tego kręgu także sporo publikowali i także u nich widać dużą różnorodność tematyczną. Nurty filozoficzne powtarzają się - zarówno przedstawiciele szkoły lwowsko-warszawskiej, jak i inni myśliciele zajmowali się historią filozofii, filozofią bytu i poznania, etyką, estetyką, logiką, fenomenologią, filozofią prawa czy mesjanizmem.

Tabela 19.

\begin{tabular}{|c|c|c|c|c|c|c|c|c|}
\hline \multirow{2}{*}{ byt } & \multicolumn{2}{|c|}{ PH } & \multicolumn{2}{c|}{ RF } & \multicolumn{2}{c|}{ KF } & SP & AK \\
\cline { 2 - 9 } & Art. & Rec. & Art. & Rec. & Art. & Rec. & & \\
\hline Bednarowski Władysław & 1 & & & & & & & \\
\hline Gołembski Władysław & & & & & 1 & 5 & & \\
\hline
\end{tabular}

Tabela 20.

\begin{tabular}{|c|c|c|c|c|c|c|c|c|}
\hline \multirow{2}{*}{ estetyka } & \multicolumn{2}{|c|}{ PH } & \multicolumn{2}{c|}{ RF } & \multicolumn{2}{c|}{ KF } & SP & AK \\
\cline { 2 - 9 } & Art. & Rec. & Art. & Rec. & Art. & Rec. & & \\
\hline Gałecki Jerzy & & & & & 1 & & & \\
\hline Segał Jakub & 2 & 3 & & 2 & & & & \\
\hline
\end{tabular}

Tabela 21.

\begin{tabular}{|c|c|c|c|c|c|c|c|c|}
\hline \multirow{2}{*}{ etyka } & \multicolumn{2}{|c|}{ PH } & \multicolumn{2}{c|}{ RF } & \multicolumn{2}{c|}{ KF } & SP & AK \\
\cline { 2 - 9 } & Art. & Rec. & Art. & Rec. & Art. & Rec. & & \\
\hline Frenkel Karol & 1 & & & & 3 & & & \\
\hline Lande Jerzy & 1 & & & & & & & \\
\hline Miciński Bolesław & & 5 & & & & 2 & & \\
\hline Siwecki Jerzy & 2 & 3 & & & & & & \\
\hline Zieleńczyk Adam & 7 & 8 & & 4 & & & & \\
\hline
\end{tabular}

Tabela 22.

\begin{tabular}{|c|c|c|c|c|c|c|c|c|}
\hline \multirow{2}{*}{ fenomenologia } & \multicolumn{2}{|c|}{ PH } & \multicolumn{2}{c|}{ RF } & \multicolumn{2}{c|}{ KF } & SP & AK \\
\cline { 2 - 10 } & Art. & Rec. & Art. & Rec. & Art. & Rec. & & \\
\hline Heinrich W. & & & & & 2 & 1 & & \\
\hline Ingarden R. & 6 & 2 & 1 & 5 & 2 & & 1 & \\
\hline Leszczyński Jan & 1 & & & & & & & \\
\hline Lissa Zofia & & & & & 1 & & & \\
\hline
\end{tabular}


Tabela 23.

\begin{tabular}{|c|c|c|c|c|c|c|c|c|}
\hline \multirow{2}{*}{ filozofia } & \multicolumn{2}{|c|}{ PH } & \multicolumn{2}{c|}{ RF } & \multicolumn{2}{c|}{ KF } & SP & AK \\
\cline { 2 - 9 } & Art. & Rec. & Art. & Rec. & Art. & Rec. & & \\
\hline Bilski Stanisław & & & & & & 7 & & \\
\hline Chrzanowski Bohdan & & & & & & & & 1 \\
\hline $\begin{array}{c}\text { Dickstein-Wieleżyńska } \\
\text { Julia }\end{array}$ & 1 & 1 & & & & & & \\
\hline $\begin{array}{c}\text { Dobrzyńska-Rybicka } \\
\text { Ludwika }\end{array}$ & & 1 & & & & & & \\
\hline $\begin{array}{c}\text { Kiersnowska-Suchorzew- } \\
\text { ska Janina }\end{array}$ & 1 & & & & & & & \\
\hline $\begin{array}{c}\text { Krzemicka (Krońska) } \\
\text { Irena }\end{array}$ & & 1 & & & & & & \\
\hline Parczewski Tomasz & & & & 1 & & & & \\
\hline Pietrzkiewicz Tadeusz & 3 & & & & 3 & & & \\
\hline Schmeidler Zygmunt & & & & & 1 & & & \\
\hline Szyłkarski Włodzimierz & 2 & 1 & & & 1 & & & \\
\hline
\end{tabular}

Tabela 24.

\begin{tabular}{|c|c|c|c|c|c|c|}
\hline \multirow{2}{*}{ filozofia kultury } & \multicolumn{2}{|c|}{ RF } & \multicolumn{2}{c|}{ KF } & SP & AK \\
\cline { 2 - 7 } & Art. & Rec. & Art. & Rec. & & \\
\hline Bystroń Jan Stanisław & & & & 2 & & \\
\hline Hessen Sergiusz & & & & & & \\
\hline Kroński Tadeusz & & & & & & \\
\hline Rubczyński W. & & 1 & 5 & 9 & & \\
\hline Stawarski (Stawar) A. & & & & 1 & & \\
\hline Witkiewicz Stanisław Ignacy & 3 & 1 & & & 1 & \\
\hline
\end{tabular}

Tabela 25.

\begin{tabular}{|c|c|c|c|c|c|c|c|c|}
\hline \multirow{2}{*}{ filozofia prawa } & \multicolumn{2}{|c|}{ PH } & \multicolumn{2}{c|}{ RF } & \multicolumn{2}{c|}{ KF } & SP & AK \\
\cline { 2 - 9 } & Art. & Rec. & Art. & Rec. & Art. & Rec. & & \\
\hline Bautro Eugeniusz & & & & & & 2 & & \\
\hline Cheliński Stanisław & & & & & 2 & & & \\
\hline Znamierowski Czesław & 4 & 2 & & 1 & & & & \\
\hline
\end{tabular}


Tabela 26.

\begin{tabular}{|c|c|c|c|c|c|c|c|c|}
\hline \multirow{2}{*}{ historia filozofii } & \multicolumn{2}{|c|}{ PH } & \multicolumn{2}{c|}{ RF } & \multicolumn{2}{c|}{ KF } & SP & AK \\
\hline & Art. & Rec. & Art. & Rec. & Art. & Rec. & & \\
\hline Bar Adam & & & & & & & & 1 \\
\hline Bornstein Benedykt & 6 & 4 & & & & & & \\
\hline Birkenmajer Aleksander & & & & 1 & & 6 & & 4 \\
\hline Chmaj Ludwik & 3 & 2 & & & 2 & 4 & & \\
\hline Czajkowski Stanisław & 3 & 6 & & & 2 & & & \\
\hline Frauenglas Edward & 1 & & & & 3 & 2 & & \\
\hline Harassek Stefan & & 1 & & & 6 & 1 & & \\
\hline Heitzman M. & 1 & & & & 7 & 7 & & 1 \\
\hline Jakubanis Henryk & & 1 & & & & & & \\
\hline Jasinowski Bogumił & 3 & 3 & & & & & & \\
\hline Kaczmarek Zdzisław & & & & & 1 & & & \\
\hline Kielski Aleksander & & & & & 1 & & & \\
\hline Kieszkowski Bohdan & 4 & 9 & & & & & & \\
\hline Kränzler F. & 1 & & & & & 1 & & \\
\hline Myślicki (Halpern) Ignacy & 4 & & 2 & 2 & & & & \\
\hline Nowicki Andrzej & 1 & & & & & & & \\
\hline Rudniański Stefan & 2 & 2 & & & & 1 & & \\
\hline Stein Edmund Menacheim & & & & & 1 & & & \\
\hline Wasilewski Michał & 1 & & & & & & & \\
\hline Wąsik Wiktor & 4 & 1 & & & & & & \\
\hline Wepsięć Jan & & & & & 1 & 2 & & \\
\hline Woyczyński Benedykt & 1 & & & & & & & \\
\hline
\end{tabular}

Tabela 27.

\begin{tabular}{|c|c|c|c|c|c|c|c|c|}
\hline \multirow{2}{*}{ logika } & \multicolumn{2}{|c|}{ PH } & \multicolumn{2}{c|}{ RF } & \multicolumn{2}{c|}{ KF } & SP & AK \\
\cline { 2 - 9 } & Art. & Rec. & Art. & Rec. & Art. & Rec. & & \\
\hline Chwistek Leon & 5 & & & & 1 & & 1 & \\
\hline $\begin{array}{c}\text { Greniewski (Kozłowski) } \\
\text { Henryk }\end{array}$ & 1 & & & & & & & \\
\hline Korcik Antoni & 1 & & & & & & & \\
\hline Kobrzyński Zygmunt & 1 & & & & & & & \\
\hline Kozłowski Władysław & & & & & 3 & & & \\
\hline Kreczmar Jerzy & & 3 & & & & & & \\
\hline Perelman Czesław & & & & & 1 & & & \\
\hline Stamm Edward & 3 & & & & & 1 & & \\
\hline Wilkosz Witold & & & & & 1 & & & \\
\hline Zaremba Stanisław & 1 & & & & & & & \\
\hline
\end{tabular}


Tabela 28.

\begin{tabular}{|c|c|c|c|c|c|c|c|c|}
\hline \multirow{2}{*}{ mesjanizm } & \multicolumn{2}{|c|}{ PH } & \multicolumn{2}{c|}{ RF } & \multicolumn{2}{c|}{ KF } & SP & AK \\
\cline { 2 - 9 } & Art. & Rec. & Art. & Rec. & Art. & Rec. & & \\
\hline Chomicz Paulin & 2 & 1 & & & 2 & 2 & & \\
\hline Lutosławski Wincenty & 1 & 9 & 1 & & & & & \\
\hline
\end{tabular}

Tabela 29.

\begin{tabular}{|c|c|c|c|c|c|c|c|c|}
\hline \multirow{2}{*}{ myśl katolicka } & \multicolumn{2}{|c|}{ PH } & \multicolumn{2}{c|}{ RF } & \multicolumn{2}{c|}{ KF } & SP & AK \\
\cline { 2 - 9 } & Art. & Rec. & Art. & Rec. & Art. & Rec. & & \\
\hline Bednarski Józef & & & 1 & & & & & \\
\hline Chojnacki Piotr & 1 & 2 & & & 1 & 1 & & \\
\hline Jakubisiak Augustyn & 1 & & & & & & & \\
\hline Januszowski Ferdynand & & 1 & & & & & & \\
\hline Joachimowski Tadeusz & & & & & & & & 2 \\
\hline Kisiel Aleksander & 1 & & & & & & & \\
\hline Kowalski K. & & 2 & & & 1 & & & \\
\hline Krzesiński Andrzej & & & & & 2 & 2 & & \\
\hline Lutyński Bronisław & & & & & & 2 & & \\
\hline Michalski K. & 1 & & & & 1 & 5 & 1 & \\
\hline Pastuszka Józef & & 3 & & & & & & \\
\hline Rutkiewicz Bohdan & 2 & 3 & & & & & & \\
\hline Stepa Jan & & 1 & & & & & & \\
\hline
\end{tabular}

Tabela 30.

\begin{tabular}{|c|c|c|c|c|c|c|c|c|}
\hline \multirow{2}{*}{ poznanie } & \multicolumn{2}{|c|}{ PH } & \multicolumn{2}{c|}{ RF } & \multicolumn{2}{c|}{ KF } & SP & AK \\
\cline { 2 - 9 } & Art. & Rec. & Art. & Rec. & Art. & Rec. & & \\
\hline Bauch Bruno & & & & & 1 & & & \\
\hline Białobrzeski Czesław & 1 & 4 & & & 1 & & & \\
\hline Fleck Ludwik & 2 & & & & & & & \\
\hline Gościcki Tadeusz & 1 & 1 & & & 1 & 3 & & \\
\hline Kodisowa Józefa & 1 & 1 & & & 2 & & & \\
\hline Konczewska Helena & & 2 & & & & & & \\
\hline Metallmann Joachim & & 1 & 1 & 3 & 5 & 11 & & \\
\hline Rajgrodzki Jakub & & & & & 1 & & & \\
\hline Żółtowski Adam & 8 & 1 & & & & & & \\
\hline
\end{tabular}


Ponadto warto podkreślić, że nie tylko filozofowie - czy to wywodzący się ze szkoły lwowsko-warszawskiej, czy też przedstawiciele innych nurtów - publikowali na łamach czasopism filozoficznych. Zgodnie z założeniami programowymi redakcje „Przeglądu”, „Ruchu” czy „Kwartalnika” zapraszały do współpracy reprezentantów innych nauk szczegółowych - socjologów, językoznawców, filologów, matematyków, historyków literatury, psychologów (Tab. 31-38). Z pewnością widać tu wpływ K. Twardowskiego, ucznia znakomitego filozofa i psychologa Franza Brentany, który - za swym mistrzem pojmował filozofię jako zespół nauk, obejmujący m.in. podstawy psychologii. W opisywanych czasopismach pojawiają się teksty przedstawicieli nawet tak niszowych dziedzin jak kryminologia czy indologia (Tab. 39). W „Przeglądzie” czy „Ruchu” znalazło się miejsce także na recenzje pióra pisarzy czy poetów (Tab. 40).

Tabela 31.

\begin{tabular}{|c|c|c|c|c|c|c|c|c|c|}
\hline \multirow{2}{*}{ inne nauki-filologia } & & \multicolumn{2}{|c|}{ PH } & \multicolumn{2}{|c|}{ RF } & \multicolumn{2}{|c|}{ KF } & SP & AK \\
\cline { 2 - 10 } & & Art. & Rec. & Art. & Rec. & Art. & Rec. & & \\
\hline Anisfeld Emanuel & Filolog polski & & & & & 1 & & & \\
\hline Czerny Zygmunt & Filolog & & & 1 & & & & & \\
\hline Seliga Stanisław & Filolog & & 1 & & & & & & \\
\hline
\end{tabular}

Tabela 32.

\begin{tabular}{|c|c|c|c|c|c|c|c|c|}
\hline \multirow{2}{*}{$\begin{array}{c}\text { inne nauki - } \\
\text { filologia klasyczna }\end{array}$} & \multicolumn{2}{|c|}{ PH } & \multicolumn{2}{c|}{ RF } & \multicolumn{2}{c|}{ KF } & SP & AK \\
\hline & Art. & Rec. & Art. & Rec. & Art. & Rec. & & \\
\hline Krokiewicz A. & 4 & 2 & & & 8 & 2 & & \\
\hline Krókowski Jerzy & & & & & & 1 & & \\
\hline Sinko Tadeusz & & & & 1 & & & & \\
\hline Zieliński Tadeusz & 1 & & & & & & & \\
\hline
\end{tabular}

Tabela 33.

\begin{tabular}{|c|c|c|c|c|c|c|c|c|}
\hline \multirow{2}{*}{$\begin{array}{c}\text { inne nauki-historia } \\
\text { literatury }\end{array}$} & \multicolumn{2}{|c|}{ PH } & \multicolumn{2}{c|}{ RF } & \multicolumn{2}{c|}{ KF } & SP & AK \\
\cline { 2 - 9 } & Art. & Rec. & Art. & Rec. & Art. & Rec. & & \\
\hline Chrzanowski Ignacy & & & & & & 3 & & \\
\hline Górski Konrad & 1 & & & & & & & \\
\hline Grabowski Tadeusz & & 1 & & & & & & \\
\hline Ujejski Jozef & & & & 1 & & & & \\
\hline
\end{tabular}


Tabela 34.

\begin{tabular}{|c|c|c|c|c|c|c|c|c|}
\hline \multirow{2}{*}{$\begin{array}{c}\text { inne nauki - } \\
\text { językoznawstwo }\end{array}$} & \multicolumn{2}{|c|}{ PH } & \multicolumn{2}{c|}{ RF } & \multicolumn{2}{c|}{ KF } & SP & AK \\
\cline { 2 - 9 } & Art. & Rec. & Art. & Rec. & Art. & Rec. & & \\
\hline Doroszewski Witold & 1 & & & & & & & \\
\hline Erdmann Edmund & 2 & & & 1 & & & & \\
\hline Rozwadowski J.M. & & & & & 2 & & & \\
\hline
\end{tabular}

Tabela 35.

\begin{tabular}{|c|c|c|c|c|c|c|c|c|}
\hline \multirow{2}{*}{ inne nauki-matematyka } & \multicolumn{2}{|c|}{ PH } & \multicolumn{2}{c|}{ RF } & \multicolumn{2}{c|}{ KF } & SP & AK \\
\cline { 2 - 9 } & Art. & Rec. & Art. & Rec. & Art. & Rec. & & \\
\hline Gołąb Stanisław & & & & & & 1 & & \\
\hline Kuratowski Kazimierz & 1 & & & & & & & \\
\hline Steinhaus Hugo & 1 & & & & & & & \\
\hline Zarycki Miron & & & & 1 & & & & \\
\hline
\end{tabular}

Tabela 36.

\begin{tabular}{|c|c|c|c|c|c|c|c|c|}
\hline \multirow{2}{*}{ inne nauki-pedagogika } & \multicolumn{2}{|c|}{ PH } & \multicolumn{2}{c|}{ RF } & \multicolumn{2}{c|}{ KF } & SP & AK \\
\hline & Art. & Rec. & Art. & Rec. & Art. & Rec. & & \\
\hline $\begin{array}{c}\text { Agatstein (Gierowski) } \\
\text { Stanisław }\end{array}$ & 1 & & & & 2 & & & \\
\hline Brossowa Anna & & & & & & 1 & & \\
\hline Heftmanowa Halina & & 1 & & & & & & \\
\hline Mirski Józef & & & & & 2 & & & \\
\hline Mysłakowski Zygmunt & 1 & & & & 4 & 2 & & \\
\hline Skórski Aleksander & 1 & & & & & & & \\
\hline Ziemnowicz Mieczysław & & & & & & 1 & & \\
\hline
\end{tabular}

Tabela 37.

\begin{tabular}{|c|c|c|c|c|c|c|c|c|}
\hline \multirow{2}{*}{ inne nauki-psychologia } & \multicolumn{2}{|c|}{ PH } & \multicolumn{2}{c|}{ RF } & \multicolumn{2}{c|}{ KF } & SP & AK \\
\hline & Art. & Rec. & Art. & Rec. & Art. & Rec. & & \\
\hline Baumgarten Franciszka & & & 2 & 4 & & & & \\
\hline Budkiewiczówna Janina & 1 & 1 & & & & & & \\
\hline Cygielstrajch Adam & 2 & & & & & & & \\
\hline Dryjski Albert & 2 & & & & 4 & & & \\
\hline $\begin{array}{c}\text { Schillerowa (Filozofówna) } \\
\text { Irena }\end{array}$ & & 4 & & & & & & \\
\hline Grzybowski Wacław & & 1 & & & & & & \\
\hline Leleszówna Helena & 1 & & & & & & & \\
\hline
\end{tabular}


Polskie czasopisma filozoficzne w okresie międzywojennym - szkic

\begin{tabular}{|c|c|c|c|c|c|c|c|c|}
\hline \multirow{2}{*}{ inne nauki-psychologia } & \multicolumn{2}{|c|}{ PH } & \multicolumn{2}{c|}{ RF } & \multicolumn{2}{c|}{ KF } & SP & AK \\
\cline { 2 - 9 } & Art. & Rec. & Art. & Rec. & Art. & Rec. & & \\
\hline Librachowa Maria & 1 & & & & & & & \\
\hline Markinówna Estera & & 2 & & & & & & \\
\hline Pieter Józef & 2 & & & & 2 & 1 & & \\
\hline Szuman Stefan & 1 & & & & 3 & 1 & & \\
\hline Zawadzki Bohdan & 1 & 1 & & & & & & \\
\hline
\end{tabular}

Tabela 38.

\begin{tabular}{|c|c|c|c|c|c|c|c|c|}
\hline \multirow{2}{*}{ inne nauki-socjologia } & \multicolumn{2}{|c|}{ PH } & \multicolumn{2}{c|}{ RF } & \multicolumn{2}{c|}{ KF } & SP & AK \\
\cline { 2 - 9 } & Art. & Rec. & Art. & Rec. & Art. & Rec. & & \\
\hline Chałasiński Józef & & & & & 1 & & & \\
\hline Hertz Aleksander & & & & & & 1 & & \\
\hline
\end{tabular}

Tabela 39.

\begin{tabular}{|c|c|c|c|c|c|c|c|c|c|}
\hline \multirow{2}{*}{ inne nauki } & & \multicolumn{2}{|c|}{ PH } & \multicolumn{2}{|c|}{ RF } & \multicolumn{2}{|c|}{ KF } & SP & AK \\
\hline & & Art. & Rec. & Art. & Rec. & Art. & Rec. & & \\
\hline Ettinger Adam & Kryminologia & 1 & & & & & & & \\
\hline $\begin{array}{c}\text { Handelsmann Marceli } \\
\text { (Maciej Romański, } \\
\text { Maciej Targowski) }\end{array}$ & Historia & & 1 & & & & & & \\
\hline Kot Stanisław & Historia & & & & & & & & 1 \\
\hline Lachs Jan & $\begin{array}{c}\text { Historia } \\
\text { medycyny }\end{array}$ & & & & & 1 & & & \\
\hline Lutman Roman & Prawo, historia & & & & 2 & & & & \\
\hline Lysakowski Adam & Bibliologia & & & & 1 & & & & \\
\hline Młynarski Feliks & Historiozofia & & & & & & & & \\
\hline Moszyński Kazimierz & Etnografia & 1 & & & & & & & \\
\hline Pawlikowski Jan & Ekonomia, prawo & & & & 1 & & & & \\
\hline Gwalbert & Indologia & & 1 & & & & & & \\
\hline Regamey Konstanty & Muzykologia & & & & & 1 & & & \\
\hline Reiss Józef & Indologia & 5 & 1 & & 2 & & & & \\
\hline Schayer Stanisław & Metodologia & & & & & 1 & & & \\
\hline Spira Zygmunt & Historia sztuki & & 1 & & & & & & \\
\hline Styger Paul & Indologia & & & & & 1 & & & \\
\hline $\begin{array}{c}\text { Willman-Grabowska } \\
\text { Helena }\end{array}$ & Psychoanaliza & 1 & & & & & & & \\
\hline Wizel Adam & Metodologia & & & & & 1 & 2 & & \\
\hline Zeidler Franciszek & Prakseologia & & & & & 1 & 4 & & \\
\hline Zieleniewski Jan & & & & & & & \\
\hline
\end{tabular}


Tabela 40 .

\begin{tabular}{|c|c|c|c|c|c|c|c|c|}
\hline \multirow{2}{*}{ literaci } & \multicolumn{2}{|c|}{ PH } & \multicolumn{2}{c|}{ RF } & \multicolumn{2}{c|}{ KF } & SP & AK \\
\cline { 2 - 8 } & Art. & Rec. & Art. & Rec. & Art. & Rec. & & \\
\hline Hulka-Laskowski Paweł & & 1 & & & & & & \\
\hline Jaworski Kazimierz & & & & 1 & & & & \\
\hline
\end{tabular}

Czy czasopisma filozoficzne starały się jakoś selekcjonować nadsyłane materiały i publikować jedynie te bliskie orientacji filozoficznej swych redaktorów? Bo przecież ilu filozofów, tyle filozofii, a każda definicja filozofii stanowi zarazem credo filozoficzne swego twórcy... $Z$ wypowiedzi redaktorów, a także powyższych tabel wynikałoby, iż nie - W. Tatarkiewicz pisał do K. Twardowskiego, redaktora Ruchu: „póki za rozprawy nie płaci się, a więc i obstalowywać ich nie można, póty „Przegląd” musi zostać magazynem dla różnorodnych utworów filozoficznych" ${ }^{26}$. Różnorodność tematyczną tego pisma potwierdził w 25-lecie jego istnienia Ignacy Myślicki w rocznicowym tekście: założeniem twórców było „skupienie najlepszej rodzimej twórczości pod hasłem tolerancji dla wszelkich stanowisk i kierunków, byleby odpowiadały wymogom naukowości w ogóle" 27 . Jak skonstatował: przez te ćwierć wieku faktycznie nikt się nie skarżył na dyskryminację z racji poglądów. Jeśli chodzi o treści zamieszczane na łamach „Kwartalnika”, podobnie jak w przypadku wcześniej istniejących tytułów, redaktorzy tego pisma także chcieli, by spotykały się na ich łamach różne orientacje filozoficzne, wychodząc z założenia, że pozwoli to pobudzić filozofów do dalszych dociekań. Tak więc w „Przeglądzie” czy „Kwartalniku” zamieszczano nawet prace Paulina Chomicza, filozofa-mesjanisty, choć te poglądy z pewnością obce były redaktorom przywoływanych pism, podobnie jak idee głoszone przez filozofów z tzw. nurtu katolickiego. Łamy otwarte dla wszystkich, stanie na stanowisku filozoficznej bezstronności - ten ideał przyświecał twórcom wszystkich czasopism ${ }^{28}$. I faktycznie widać, że część filozofów i naukowców, wywodzących się z różnych środowisk, reprezentujących różne dziedziny zainteresowań, publikowała na łamach wszystkich analizowanych czasopism, na przykład Zawirski, Gawecki, Ingarden, Kotarbiński, Krokiewicz, Metallmann, Kokoszyńska-Lutmanowa czy Tatarkiewicz.

26 Por. R. Jadczak, 80 lat..., s. 101.

27 I. Myślicki, Przegląd Filozoficzny w ciagu 25 lat swego istnienia (1897-1922), „Przegląd Filozoficzny" 1922, t. 25, z. 4, s. I.

28 Por. W. Tatarkiewicz, Zarys dziejów filozofii w Polsce, Kraków 1948, s. 30. 


\section{Zakończenie}

Analiza zawartości czasopism filozoficznych pozwala na ukazanie kondycji filozofii w danej epoce. Oczywiście szczegółowe przedstawienie tego zagadnienia wymagałoby stanowczo obszerniejszych studiów. Ale nawet wstępne badania pozwalają stwierdzić, że epokowe prace filozoficzne okresu międzywojennego, stworzone w kręgu renomowanej szkoły lwowsko-warszawskiej teksty K. Ajdukiewicza, T. Kotarbińskiego, T. Czeżowskiego, S. Leśniewskiego, A. Tarskiego, M. i S. Ossowskich czy W. Tatarkiewicza - publikowano właśnie na łamach czasopism filozoficznych. Podobnie jak dzieła światowej sławy fenomenologa R. Ingardena czy niezwykle oryginalnego filozofia kultury, jakim był S.I. Witkiewicz. Także przedstawiciele neotomizmu, K. Michalski czy P. Chojnacki, znaleźli swe miejsce w czasopiśmiennictwie filozoficznym. Czasopismom naukowym stawia się zwykle zadania rozwoju nauki, upowszechniania jej dokonań oraz informowania o stanie rozwoju danej dyscypliny w świecie. W tym kontekście opisane periodyki z pewnością odegrały wyznaczoną im rolę, stanowiąc „wizytówkę” ówczesnej filozofii w Polsce.

\section{Bibliografia}

\section{Źródła}

„Archiwum Historii i Filozofii Medycyny” 1925-1931 [dostępny w: Łódzka Regionalna Biblioteka Cyfrowa; http://cybra.p.lodz.pl/dlibra/docmetadata?id=8769\&from=\&dirid$\mathrm{s}=1 \& v e r \_$id $=\& l p=15 \& Q \mathrm{I}=6 \mathrm{C} 8 \mathrm{AF} 473 \mathrm{ABA} 16 \mathrm{~B} 6849 \mathrm{C} 00 \mathrm{CB} 8 \mathrm{~F} 68 \mathrm{~A} 90 \mathrm{D} 3-18 \#$ structure]. „Archiwum Komisji do Badania Historii Filozofii w Polsce” 1915-1937 [dostępny w: Śląska Biblioteka Cyfrowa; https://sbc.org.pl/dlibra/publication/28582/edition/25642\#structure]. „Biuletyn Posiedzeń Naukowych Warszawskiego Instytutu Filozoficznego” 1923-1926 [dostępny w: Cyfrowa Biblioteka Narodowa Polona; https://polona.pl/item/biuletyn-posiedzen-naukowych-warszawskiego-instytutu-filozoficznego-1924-1925,NzkyNzgzMDQ/0/\#info:metadata].

„Kwartalnik Filozoficzny” 1922-1939 [dostępny w: Śląska Biblioteka Cyfrowa; https:// sbc.org.pl/dlibra/publication/24854/edition/22011\#structure].

„Polski Przegląd Tomistyczny” 1939 [dostępny w: Dominikańska Biblioteka Cyfrowa; https://bc.dominikanie.pl/dlibra/show-content/publication/edition/233?id=233].

„Przegląd Filozoficzny” 1897-1939 [dostępny w: Wielkopolska Biblioteka Cyfrowa; https://www.wbc.poznan.pl/dlibra/publication/106989/edition/120368\#structure].

„Ruch Filozoficzny” 1911-1938 [dostępny w: Śląska Biblioteka Cyfrowa; https://www. wbc.poznan.pl/dlibra/publication/135105/edition/145834\#structure].

„Studia Gnesnensia” 1933- 
„Studia Philosophica” 1935- [dostępny w: Śląska Biblioteka Cyfrowa; https://sbc.org.pl/ dlibra/publication/24411/edition/21615\#structure].

„Wronskiana” 1939

Opracowania

Bochenek K. i in., Filozofia polska okresu międzywojennego. Zarys problematyki, Gdynia 2013.

Borzym S., Filozofia polska 1900-1950, Wrocław 1991.

Encyklopedia filozofii polskiej. T. 1-2, red. A. Maryniarczyk, Lublin 2011.

Filozofia w Polsce. Stownik pisarzy, Wrocław 1971

Jadacki J., Filozofia polska XIX i XX wieku. T. 2: Wiek XIX, Warszawa 2015.

Jadczak R., 80 lat „,Ruchu Filozoficznego”, „Ruch Filozoficzny” 1991, nr 2, s. 99-105.

Myślicki I., Przegląd Filozoficzny w ciagu 25 lat swego istnienia (1897-1922), „Przegląd Filozoficzny" 1922, t. 25, z. 4, s. I-VII.

Paczkowski A., Prasa polska w latach 1918-1939, Warszawa 1980.

Skoczyński J., Woleński J., Historia filozofii polskiej, Kraków 2010.

Tatarkiewicz W., Historia filozofii. T. 3, Warszawa 1990.

Tatarkiewicz W., Wypowiedź w dyskusji nad książka Konrada Olchowicza „Ćwierć wieku z Kurierem Warszawskim”, „Kronika Warszawy” 1980, nr 4 (44), s. 79-81.

Tatarkiewicz W., Zarys dziejów filozofii w Polsce, Kraków 1948.

Woleński J., Filozofia szkoły lwowsko-warszawskiej, Wrocław 1986.

Woleński J., O „,Przeglądzie Filozoficznym”, „Ruch Filozoficzny” 1985, nr 1-2, s. 37-44.

Wrona G., Polskie czasopisma naukowe w latach 1918-1939, Kraków 2005.

Zarys dziejów filozofii polskiej 1815-1918, red. A. Walicki, Warszawa 1986. 